\title{
The Evolution and Consolidation of External Dispute Resolution Schemes in the Financial Sector: From the Banking Ombudsman to the Australian Financial Complaints Authority
}

\author{
Ian Ramsay and Miranda Webster*
}

\begin{abstract}
The Australian Banking Industry Ombudsman ('ABIO') was the first external dispute resolution ('EDR') scheme set up and funded by industry members at a national level in Australia. It came into operation in 1990. The ABIO was a significant first step in the development of EDR schemes to resolve disputes between financial service providers and consumers. At one stage there were seven different industry-funded EDR schemes in existence in the financial sector. However, the existence of multiple schemes proved to be problematic. Several of the EDR schemes merged in 2008 to create the Financial Ombudsman Service ('FOS'), and in November 2018, FOS, the Credit and Investments Ombudsman and the Superannuation Complaints Tribunal were replaced by a single body, the Australian Financial Complaints Authority. This article examines the establishment of the ABIO, outlines the expansion of industry-established EDR schemes operating in the financial sector, and then considers the arguments for the consolidation of the schemes.
\end{abstract}

\section{Introduction}

In 1989, the Australian Banking Industry Ombudsman ('ABIO') was established. ${ }^{1}$ It came into operation in $1990 .^{2}$ The ABIO was not only the first external dispute resolution ('EDR') scheme to be created by industry members in the Australian financial sector, it was the first Australia-wide, industry-funded EDR scheme. ${ }^{3}$ EDR schemes were set up by particular industries or sectors of industries in the late 1980s and the early 1990s to provide consumers with low-cost, quick and informal mechanisms to resolve their disputes with service providers. ${ }^{4}$ The Australian Securities and Investments Commission ('ASIC') has highlighted that an EDR

\footnotetext{
* Ian Ramsay is the Harold Ford Professor of Commercial Law, Redmond Barry Distinguished Professor and Director of the Centre for Corporate Law, Melbourne Law School, the University of Melbourne. Miranda Webster is a Research Fellow, Melbourne Law School, the University of Melbourne.

${ }^{1}$ Gregory Burton, ‘A Banking Ombudsman for Australia' (1990) 1 Journal of Banking and Finance Law and Practice 29, 29.

2 Banking and Financial Services Ombudsman Limited, Review of the Banking and Financial Services Ombudsman Scheme: Background Paper (June 2004) 16.

${ }^{3}$ Australian Banking Industry Ombudsman Limited, Annual Report 1990-1991 (1991) 5; Graham McDonald, 'The Australian Banking Industry Ombudsman' (Presented at the Banking and Law Practice Conference 1992) $<$ http://bfsla.org/wp-content/uploads/papers/1992/Banking\%20Ombudsman\%20-\%20McDonald.pdf > 149; Parliament of the Commonwealth of Australia, House of Representatives Standing Committee on Finance and Public Administration, A Pocket Full of Change (November 1991) 397 [20.81].

4 Financial System Inquiry, Final Report (March 1997) 286; Banking and Financial Services Ombudsman Limited, Review of the Banking and Financial Services Ombudsman Scheme: Background Paper (June 2004$) 8$.
} 
scheme provides an independent mechanism for dealing with complaints that cannot be resolved by financial service providers through their own internal dispute resolution procedures. ${ }^{5}$ EDR schemes are also more accessible than formal legal proceedings, as they are generally free to the complainant, they are informal and they do not require legal representation. ${ }^{6}$ An effective EDR process therefore encourages consumers to avoid slow and costly court action. ${ }^{7}$ These schemes also provide an opportunity to improve industry standards of conduct and to improve relations between service providers and consumers; ${ }^{8}$ and the independence and accessibility of EDR schemes also improves consumer confidence in the financial services sector more generally. ${ }^{9}$

From 1998, ASIC began to make it a licensing condition that certain financial service providers have an internal dispute resolution procedure and be a member of one or more ASIC-approved EDR schemes. By 2002, all financial services providers were required to have a dispute resolution system that covered complaints by retail clients. ${ }^{10}$ At one stage there were seven different EDR schemes in existence that had been approved by ASIC - but by 2009 only two ASIC-approved schemes remained, and these were replaced by a single body, the Australian Financial Complaints Authority ('AFCA'), in November 2018. ${ }^{11}$

In this article, we provide a history of the industry-established EDR schemes that have operated in the financial sector, with a particular focus on the first national EDR scheme - the ABIO. We then highlight the reasons for the consolidation of these schemes into a single EDR scheme.

\section{A history of industry-established EDR schemes in the financial sector}

In this section we consider the creation of the ABIO and the experience of its first few years of operation. We then consider the expansion of financial sector EDR schemes and the regulatory framework that underpinned those schemes.

\footnotetext{
${ }^{5}$ Australian Securities and Investments Commission ('ASIC'), Dispute resolution - Review of RG 139 and RG 165, Consultation Paper 102 (September 2008) 8.

${ }^{6}$ ASIC, Dispute resolution - Review of RG 139 and RG 165, Consultation Paper 102 (September 2008) 8; Colin Neave and John Pinnock, 'Setting the Scene: Industry-based Customer Dispute Resolution Schemes' (Presented at National Alternative Dispute Resolution Advisory Council, 4-5 September 2003, Sydney) 20.

${ }^{7}$ ASIC, Dispute resolution - Review of RG 139 and RG 165, Consultation Paper 102 (September 2008) 9.

${ }^{8}$ ASIC, Approval and oversight of external dispute resolution schemes, Regulatory Guide 139 (June 2013$) 12$.

${ }^{9}$ ASIC, Dispute resolution - Review of RG 139 and RG 165, Consultation Paper 102 (September 2008) 9.

${ }^{10}$ Corporations Act 2001 (Cth) ss 912A(1)(g), (2), 1017G(2) as inserted by Financial Services Reform Act 2001 (Cth) sch 1 item 1. These provisions came into effect in March 2002.

${ }^{11}$ See ASIC, 'ASIC-approved Dispute Resolution Schemes' <https://asic.gov.au/regulatory-resources/financialservices/dispute-resolution/asic-approved-dispute-resolution-schemes/>; Australian Financial Complaints Authority ('AFCA'), 'Australian Financial Complaints Authority' $<$ https://www.afca.org.au $>$. For information on the development of AFCA, see Ian Ramsay, Julie Abramson and Alan Kirkland, Review of the Financial System External Dispute Resolution and Complaints Framework: Final Report (April 2017); The Treasury, Australian Government, 'External Dispute Resolution and Complaints Framework' $<$ https://reasury.gov.au/consultation/external-dispute-resolution-and-complaints-framework/>; The Treasury, Australian Government, Consultation Paper: Improving Dispute Resolution in the Financial System (May 2017). The members of the expert panel for the Review of the Financial System External Dispute Resolution and Complaints Framework were Professor Ian Ramsay (Chair), Julie Abramson and Alan Kirkland.
} 


\section{A. The establishment of the ABIO}

In 1989, after consultation with government and consumer groups, the Australian Bankers' Association ('ABA') established the ABIO. ${ }^{12}$ The ABIO was modelled on the Office of the Banking Ombudsman in the United Kingdom, ${ }^{13}$ and was set up as a corporation limited by guarantee. ${ }^{14}$ It had 17 founding bank members. ${ }^{15}$ Its purpose was to provide individual customers of member banks with an independent mechanism for the resolution of their complaints against the banks. ${ }^{16}$ The ABIO came into operation in $1990,{ }^{17}$ and it was the first independent, EDR scheme to be implemented by an Australian industry on a national scale. ${ }^{18}$

The ABIO had three key elements: a Board of directors (six representatives from member banks and a Reserve Bank representative), a Council (three bank representatives and three consumer representatives, and an independent Chairman), and the Ombudsman. ${ }^{19}$ The Council acted as a buffer between the Ombudsman and the Board to ensure the Ombudsman's independence from the funding banks. ${ }^{20}$ This structure meant that the bank-controlled Board was only responsible for approving funding for the ABIO (to be paid by the member banks) and for deciding on the content of the terms of reference and making final decisions on changes

\footnotetext{
12 Australian Banking Industry Ombudsman Limited, Annual Report 1990-1991 (1991) 10. The ABIO’s first Annual Report noted that the establishment of the ABIO was an acknowledgement by the major banks that they needed to 'improve their service and public image'.

${ }^{13}$ Australian Banking Industry Ombudsman Limited, Annual Report 1990-1991 (1991) 11; Gregory Burton, 'A Banking Ombudsman for Australia' (1990) 1 Journal of Banking and Finance Law and Practice 29, 29; W S Weerasooria, 'The Australian Banking Ombudsman Scheme - Recent Developments' (1992) 2 Australian Journal of Corporate Law 225, 225.

14 Banking and Financial Services Ombudsman Limited, Review of the Banking and Financial Services Ombudsman Scheme: Background Paper (June 2004) 17; Gregory Burton, 'A Banking Ombudsman for Australia' (1990) 1 Journal of Banking and Finance Law and Practice 29, 32; Parliament of the Commonwealth of Australia, House of Representatives Standing Committee on Finance and Public Administration, A Pocket Full of Change (November 1991) 398 [20.84].

15 Australian Banking Industry Ombudsman Limited, Annual Report 1990-1991 (1991) 5; Parliament of the Commonwealth of Australia, House of Representatives Standing Committee on Finance and Public Administration, A Pocket Full of Change (November 1991) 398 [20.83].
}

16 Australian Banking Industry Ombudsman Limited, Annual Report 1990-1991 (1991) 10; Parliament of the Commonwealth of Australia, House of Representatives Standing Committee on Finance and Public Administration, A Pocket Full of Change (November 1991) 396 [20.75], 397 [20.81].

17 Banking and Financial Services Ombudsman Limited, Review of the Banking and Financial Services Ombudsman Scheme: Background Paper (June 2004) 16; Parliament of the Commonwealth of Australia, House of Representatives Standing Committee on Finance and Public Administration, A Pocket Full of Change (November 1991) 397 [20.81].

18 Australian Banking Industry Ombudsman Limited, Annual Report 1990-1991 (1991) 5.

${ }^{19}$ Australian Banking Industry Ombudsman Limited, Annual Report 1991-1992 (1992) 19; Banking and Financial Services Ombudsman Limited, Review of the Banking and Financial Services Ombudsman Scheme: Background Paper (June 2004) 17. The governing structure of the ABIO changed on 1 September 2001, with the former Council and Board structure being replaced with a single Board of Directors comprising an Independent Chair, two consumer, one small business and three bank representatives: Australian Banking Industry Ombudsman Limited, Annual Report 2001-2002 (2002) 2.

${ }^{20}$ Australian Banking Industry Ombudsman Limited, Annual Report 1991-1992 (1992) 18. 
to the terms of reference. ${ }^{21}$ The Ombudsman was appointed by the Council and not the Board and was required to make decisions independently but answer to the Council on administrative matters. ${ }^{22}$ The Council also advised the Board regarding the funds necessary for the ABIO's operation (so that the Ombudsman was not required to directly negotiate with the banks on this), assisted with policy development and made recommendations to the Board on changes to the terms of reference (following consideration of suggestions made by the Ombudsman). ${ }^{23}$ The first Chairman of the Council was Sir Ninian Stephen, a former Justice of the High Court and Governor General of Australia, and the first Ombudsman was Graham McDonald, who had been given leave from his position at the Administrative Appeals Tribunal to establish the ABIO.$^{24}$ Having a Chairman of Council with such a high status, supported by a committee of equal numbers of consumers and industry representatives, helped allay concerns regarding the ability of the Ombudsman to remain independent from the banks. ${ }^{25}$

The Ombudsman's main role was to consider disputes relating to the provision within Australia of banking services to any individual by a bank that was a member of the ABIO. ${ }^{26}$ The Ombudsman had jurisdiction to consider claims involving amounts of up to $\$ 100,000 .{ }^{27}$ However, the Ombudsman was established as 'an office of last resort'. ${ }^{28}$ Accordingly, the Ombudsman could only consider a complaint if the senior management of the bank named in the complaint had already had the opportunity to consider the complaint. ${ }^{29}$ Nevertheless, the first Annual Report by the Ombudsman's office noted that many complainants accessed the Ombudsman's office first rather than trying to resolve the problem with the bank. ${ }^{30}$ This was because customers did not know the appropriate bank channels through which to pursue their complaint (and it also may have been because the banks had been subject to widespread public criticism in that past year). ${ }^{31}$ The Ombudsman therefore adopted procedures whereby all

\footnotetext{
${ }^{21}$ Australian Banking Industry Ombudsman Limited, Annual Report 1991-1992 (1992) 19; Graham McDonald, 'The Australian Banking Industry Ombudsman' (Presented at the Banking and Law Practice Conference 1992) $<$ http://bfsla.org/wp-content/uploads/papers/1992/Banking\%20Ombudsman\%20-\%20McDonald.pdf $>150$.

${ }^{22}$ Australian Banking Industry Ombudsman Limited, Annual Report 1991-1992 (1992) 18; Banking and Financial Services Ombudsman Limited, Review of the Banking and Financial Services Ombudsman Scheme: Background Paper (June 2004) 17; Graham McDonald, 'The Australian Banking Industry Ombudsman' (Presented at the Banking and Law Practice Conference 1992) <http://bfsla.org/wpcontent/uploads/papers/1992/Banking\%20Ombudsman\%20-\%20McDonald.pdf $>150$.
}

23 Graham McDonald, 'The Australian Banking Industry Ombudsman' (Presented at the Banking and Law Practice Conference 1992) <http://bfsla.org/wp-content/uploads/papers/1992/Banking\%20Ombudsman\%20$\% 20$ McDonald.pdf $>150$.

${ }^{24}$ Australian Banking Industry Ombudsman Limited, Annual Report 1990-1991 (1991) 10, 16; Banking and Financial Services Ombudsman Limited, Review of the Banking and Financial Services Ombudsman Scheme: Background Paper (June 2004) 17.

${ }^{25}$ Interview by the authors with Mr Graham McDonald conducted on 17 April 2019.

${ }^{26}$ Australian Banking Industry Ombudsman Limited, Terms of Reference para 1, as published in Australian Banking Industry Ombudsman Limited, Annual Report 1990-1991 (1991) Attachment B ('ABIO Terms of Reference').

${ }^{27}$ ABIO Terms of Reference, para 17(d).

${ }^{28}$ Australian Banking Industry Ombudsman Limited, Annual Report 1990-1991 (1991) 12; Parliament of the Commonwealth of Australia, House of Representatives Standing Committee on Finance and Public Administration, A Pocket Full of Change (November 1991) 398 [20.87].

${ }^{29}$ ABIO Terms of Reference, para 20(b).

${ }^{30}$ Australian Banking Industry Ombudsman Limited, Annual Report 1990-1991 (1991) 7.

${ }^{31}$ Australian Banking Industry Ombudsman Limited, Annual Report 1990-1991 (1991) 7. 
complaints were forwarded to the relevant banks, prior to any intervention by the Ombudsman's office. ${ }^{32}$

The first Annual Report highlighted that the majority of complaints were resolved by referral to the banks, 'either by the bank agreeing it had made an error and taking corrective action or by explaining to the satisfaction of the customer the banking process applied to the transaction in dispute. ${ }^{33}$ In the first year of the ABIO's operation, the ABIO received 2,626 written complaints and around 26,000 telephone inquiries. ${ }^{34}$ Of the 2,626 complaints, 1,945 were concluded within that year ( 829 of these concluded complaints were ruled by the Ombudsman to be outside the Terms of Reference - 1,116 concluded complaints were within the Ombudsman's Terms of Reference); 681 remained open at 30 June $1991 .{ }^{35}$ Of the 1,116 closed matters that were within the Ombudsman's jurisdiction, 740 were resolved by the banks after being referred by the Ombudsman to the bank. ${ }^{36}$

If a matter was not resolved upon referral to the bank, then it could be classified as a 'dispute' requiring investigation and action by the Ombudsman's office. ${ }^{37}$ This could lead to the Ombudsman staff negotiating with the bank to achieve a settlement and, if this was unsuccessful, there could be a conciliation conference between the Ombudsman, the bank and the customer to settle by agreement, or the Ombudsman could make a recommendation. ${ }^{38}$ If the customer, but not the bank, accepted the Ombudsman's recommendation, the Ombudsman would make an award, which would be binding on the bank if accepted by the customer. ${ }^{39}$

The decision by the participating banks to relinquish, by agreement, their rights of access to the courts in favour of a customer who accepted the Ombudsman's award was a very significant element of the ABIO. ${ }^{40}$ By contrast, if a complainant was unsatisfied with a decision made by the Ombudsman, they could choose to litigate in court. ${ }^{41}$ By not requiring complainants to relinquish their rights of access to the courts, the ABIO was viewed as very 'complainant friendly'. ${ }^{42}$ Other significant features of the ABIO's Terms of Reference were that the Ombudsman was not bound by any legal rule of evidence, ${ }^{43}$ and in making any recommendation or award, the Ombudsman was required to do what he or she considered to be 'fair in all the circumstances' and to 'observe any applicable rule of law or relevant judicial

\footnotetext{
32 Australian Banking Industry Ombudsman Limited, Annual Report 1990-1991 (1991) 7.

33 Australian Banking Industry Ombudsman Limited, Annual Report 1990-1991 (1991) 7.

${ }^{34}$ Australian Banking Industry Ombudsman Limited, Annual Report 1990-1991 (1991) 28.

35 Australian Banking Industry Ombudsman Limited, Annual Report 1990-1991 (1991) 31.

${ }^{36}$ Australian Banking Industry Ombudsman Limited, Annual Report 1990-1991 (1991) 42.

${ }^{37}$ Australian Banking Industry Ombudsman Limited, Annual Report 1990-1991 (1991) 23.

${ }^{38}$ Australian Banking Industry Ombudsman Limited, Annual Report 1990-1991 (1991) 22, 25.

${ }^{39}$ Australian Banking Industry Ombudsman Limited, Annual Report 1990-1991 (1991) 22, 25.

40 Graham McDonald, 'The Australian Banking Industry Ombudsman' (Presented at the Banking and Law Practice Conference 1992) <http://bfsla.org/wp-content/uploads/papers/1992/Banking\%20Ombudsman\%20$\% 20$ McDonald.pdf $>149$.

${ }^{41}$ Parliament of the Commonwealth of Australia, House of Representatives Standing Committee on Finance and Public Administration, A Pocket Full of Change (November 1991) 399 [20.88].

42 Graham McDonald, 'The Australian Banking Industry Ombudsman' (Presented at the Banking and Law Practice Conference 1992) <http://bfsla.org/wp-content/uploads/papers/1992/Banking\%20Ombudsman\%20$\% 20$ McDonald.pdf> 149.

${ }^{43}$ ABIO Terms of Reference, para 9.
} 
authority' and to 'have regard to general principles of good banking practice and any relevant code of practice applicable to the subject-matter of the complainant'. ${ }^{44}$

In the first year of the ABIO's operation, the majority of the 2,626 written complaints concerned lending products $(22.6 \%$ of complaints concerned housing finance, $17.4 \%$ concerned consumer finance and $13.4 \%$ concerned business finance), with the second-highest category relating to payment systems complaints ( $11.7 \%$ of complaints $).{ }^{45}$ Customers benefited by a minimum of $\$ 1.43$ million in the settlement of 1,116 cases, ${ }^{46}$ with the majority of payments made to customers being for amounts of less than $\$ 1,000 .^{47}$

In November 1991, the Standing Committee on Finance and Public Administration inquiry into banking, known as the Martin Committee, noted that it was impressed at the effectiveness of the ABIO 'after such a short time of operation'. ${ }^{48}$ The Committee noted that lifting the monetary threshold could make the ABIO more expensive to operate, but nevertheless recommended that the monetary limit be increased to $\$ 200,000$ and that small proprietary companies should be included. ${ }^{49}$ The ABIO Council and Ombudsman considered this recommendation, but felt that the scheme needed more time to consolidate its operations 'in the face of growing complaint volumes and increasing staff numbers'. ${ }^{50}$

There was a substantial growth in the use of the ABIO in its second year of operation - 4,167 written complaints and 22,000 telephone complaints. ${ }^{51}$ During that year, the Ombudsman had only been required to proceed to a formal recommendation or binding award in 48 cases, despite thousands of complaints - this exemplified the success of the Ombudsman and his staff in working with consumers and banks to resolve disputes. ${ }^{52}$ Nevertheless, the Ombudsman Graham McDonald highlighted the importance of the public gaining a greater understanding of the banker-customer relationship:

\footnotetext{
${ }^{44}$ ABIO Terms of Reference, para 15.

45 Australian Banking Industry Ombudsman Limited, Annual Report 1990-1991 (1991) 54-55; Graham McDonald, 'The Australian Banking Industry Ombudsman' (Presented at the Banking and Law Practice Conference 1992) <http://bfsla.org/wp-content/uploads/papers/1992/Banking\%20Ombudsman\%20\%20McDonald.pdf> 156; W S Weerasooria, 'The Australian Banking Ombudsman Scheme - Recent Developments' (1992) 2 Australian Journal of Corporate Law 225, 227; Parliament of the Commonwealth of Australia, House of Representatives Standing Committee on Finance and Public Administration, A Pocket Full of Change (November 1991) 399 [20.91].

${ }^{46}$ Australian Banking Industry Ombudsman Limited, Annual Report 1990-1991 (1991) 43.

${ }^{47}$ Australian Banking Industry Ombudsman Limited, Annual Report 1990-1991 (1991) 43.

${ }^{48}$ Parliament of the Commonwealth of Australia, House of Representatives Standing Committee on Finance and Public Administration, A Pocket Full of Change (November 1991) 402 [20.107].

${ }^{49}$ Parliament of the Commonwealth of Australia, House of Representatives Standing Committee on Finance and Public Administration, A Pocket Full of Change (November 1991) 402 [20.108]-[20.109], 403 [20.114].
}

50 Australian Banking Industry Ombudsman Limited, Annual Report 1991-1992 (1992) 11. Note that by November 1993, Mr Graham McDonald argued that the Ombudsman should be able to hear complaints from small businesses and claims of up to \$200,000: Jacquelyn Hole, 'Bank Watchdog Critical of Scheme', Sydney Morning Herald, 10 November 1993, p 6. The monetary limit was later extended to \$150,000 in 1996 and to \$280,000 in December 2004: Banking and Financial Services Ombudsman Limited, Review of the Banking and Financial Services Ombudsman Scheme: Background Paper (June 2004) 39; Productivity Commission, Australian Government, Review of Australia's Consumer Policy Framework: Productivity Commission Inquiry Report, Final Report (April 2008) vol 2, 208

${ }^{51}$ Australian Banking Industry Ombudsman Limited, Annual Report 1991-1992 (1992) 4.

52 Australian Banking Industry Ombudsman Limited, Annual Report 1991-1992 (1992) 4. 
'It is important for customers to realise that the banker is dealing in the buying and selling of money with a view to making a profit for the shareholders of the bank. ...[T]he customer must clearly understand that when he or she approaches a bank manager they are doing so on the basis that the bank manager's prime responsibility is to make a profit for the shareholders. ... As it is, the majority of customers in dispute with the banks say they have ended up in conflict because they expected the bank to extend to them the duty the banker, in fact, owed primarily to the shareholders of the bank. ${ }^{53}$

Additionally, the fact that so many of the complaints related to 'disputes about terms, conditions and fees with respect to loans' indicated that some customers were not informed (or sufficiently informed) or did not understand the details of important information about the financial products that they were purchasing. ${ }^{54}$ Also, the majority of written complaints were still coming direct from the public, rather than after referral to the banks. This indicated that while the banks had implemented enhanced complaint resolution mechanisms, more work needed to be done to ensure that customers knew about them. ${ }^{55}$

In September 1992, following a major controversy regarding the wrongful collection of thirdparty cheques into a trust account, which had led to many complaints (486 complaints for the year ended 30 June 1992), the ABIO Board excluded complaints concerning third-party cheques from the Ombudsman's jurisdiction. ${ }^{56}$ In May that year, the Ombudsman had found that ANZ and NAB had acted negligently in processing cheques, which had been made out to third parties, into the account of investment company Security Directors Pty Ltd. ${ }^{57}$ (By September, ANZ and NAB had paid out more than $\$ 5.3$ million to customers of the failed company since the Ombudsman's original decision. ${ }^{58}$ ) A memo circulated to the banks by the ABA accused the Ombudsman of 'bias' against the industry. ${ }^{59}$ The proposed changes to the Terms of Reference became public due to the ABA inadvertently sending a copy of the draft document to the parliamentary banking inquiry. ${ }^{60}$ The Ombudsman noted in the third Annual Report that it was 'open to conclude that the changes [to the Terms of Reference], and the way in which they became public, led to a lessening of confidence in the industry's approach to the Scheme', ${ }^{61}$ also, the narrowing of the Ombudsman's jurisdiction 'contributed to a high proportion of complainants being excluded from the Scheme'. ${ }^{6}$

\footnotetext{
53 Australian Banking Industry Ombudsman Limited, Annual Report 1991-1992 (1992) 6.

${ }^{54}$ Australian Banking Industry Ombudsman Limited, Annual Report 1991-1992 (1992) 6.

55 Australian Banking Industry Ombudsman Limited, Annual Report 1991-1992 (1992) 5.

${ }^{56}$ Australian Banking Industry Ombudsman Limited, Annual Report 1991-1992 (1992) 57; W S Weerasooria, 'The Australian Banking Ombudsman Scheme - Recent Developments' (1992) 2 Australian Journal of Corporate Law 225, 230.

${ }^{57}$ Steve Lewis, 'Banks Attacked on Ombudsman Ban', The Australian Financial Review, 21 September 1992, p 34.

${ }^{58}$ Steve Lewis, 'Banks Attacked on Ombudsman Ban', The Australian Financial Review, 21 September 1992, p 34.

${ }^{59}$ Steve Lewis, 'Banks Move to Muzzle Watchdog', The Australian Financial Review, 28 July 1992, p 1.

${ }^{60}$ Steve Lewis, 'Banks Move to Muzzle Watchdog', The Australian Financial Review, 28 July 1992, p 1.

${ }^{61}$ Australian Banking Industry Ombudsman Limited, Annual Report 1992-1993 (1993) 7, as cited in Wickrema Weerasooria and Nerida Wallace, Banker-Customer: Resolving Banking Disputes (Longman Professional, 1994) $\mathrm{xi}$.

${ }^{62}$ Australian Banking Industry Ombudsman Limited, Annual Report 1992-1993 (1993) 7, as cited in Wickrema Weerasooria and Nerida Wallace, Banker-Customer: Resolving Banking Disputes (Longman Professional 1994) $\mathrm{xi}$.
} 
The authors interviewed the first Banking Ombudsman, Graham McDonald, to gain further insight into the first few years of the operation of the scheme. ${ }^{63}$ He noted as follows.

There were several key drivers and reasons for the development of the scheme. ${ }^{64}$ Two drivers for the ABIO scheme were the adverse media coverage and the public concern regarding the banks encouraging farmers to take up foreign currency loans (which led to financial difficulty and even bankruptcy due to currency changes and interest rate increases) and allowing guarantees to be provided by non-English-speaking parents to enable their children to establish businesses (many of which subsequently failed). The consumer movement and the fact that a similar scheme had been established in the UK were also reasons for the establishment of the scheme.

The initial challenges in establishing the ABIO scheme were setting up an office, communicating the existence of the scheme to consumers, and putting in place procedures that would lead to outcomes which could be publicly scrutinised. An office was established in Carlton, rather than within the central business district of Melbourne, so as to create some physical distance from the banks. It was agreed that the banks would provide a senior staff member to provide input on what constituted 'best banking practice' and that position was rotated between the banks on an annual basis. A number of investigation staff were appointed to collect the necessary documentation regarding complaints. Once the facts were established, the investigation staff attempted to negotiate the settlement of claims. Regular training sessions in alternative dispute resolution were instigated, and weekly meetings with the investigation staff were held where each staff member would provide the background facts on their most difficult case followed by discussion as to the outcome. This process provided me with the opportunity of establishing the principles to be applied, as we had no precedents to rely upon.

Pamphlets about the Ombudsman's office were published to be displayed in every bank. I would check when visiting regional areas to ensure that the pamphlets were being publicly displayed. Most complaints were resolved by the banks agreeing to a compromise or accepting the preliminary decision made by the Ombudsman. If not, or if the factual issues were unclear from the correspondence, a conference where both parties were present was undertaken. This involved travelling to where the consumer was located. The conferences were conducted in a neutral setting (eg local consumer affairs offices or at shire buildings, motels etc). Travel provided an opportunity to promote information about the scheme to regional audiences through local press, radio and meeting with interest groups.

The banks generally did not have well-developed internal dispute resolution systems. While some banks had central dispute resolution divisions, these were designed more to support the staff in the branch in which the complaint had arisen, in an advisory role, rather than to exercise a directive function in securing a resolution of the complaint. There was little or no coordinated data collection on complaints (so that the banks could learn from them), and the banks did not have any universally-agreed system by which to classify the complaints, nor was there any universal criteria for what actually constituted a complaint. Accordingly, the Ombudsman's

\footnotetext{
${ }^{63}$ The interview was conducted on 17 April 2019.

${ }^{64}$ Note that the House of Representatives Standing Committee on Finance and Public Administration led by Stephen Martin ('Martin Committee') stated that the inability of the average consumer to litigate against a bank (due to time and cost barriers) and the failure of the banks to have adequate internal dispute resolution mechanisms in place were the key reasons for developing the scheme: Parliament of the Commonwealth of Australia, House of Representatives Standing Committee on Finance and Public Administration, A Pocket Full of Change (November 1991) 397 [20.76].
} 
office set up a system which categorised complaints so that it was possible to compare the performance of the member banks.

There were a few key changes to the jurisdiction of the Ombudsman in later years. Originally, only individual bank customers could lodge complaints against bank members, but in 1998 the ABIO's terms of reference were amended to allow customers of small businesses to lodge complaints. ${ }^{65}$ In 2003, the ABIO was renamed the Banking and Financial Services Ombudsman ('BFSO') and the scope of the scheme was extended to allow non-bank financial services providers to become members. ${ }^{66}$ Also, the monetary limit for complaints was increased to $\$ 150,000$ in 1996 and to $\$ 280,000$ in December $2004 .{ }^{67}$

\section{B. The expansion of the financial sector EDR schemes}

After the commencement of the ABIO in 1990, several other EDR schemes were set up by financial sector industry members to deal with disputes between consumers and service providers. ${ }^{68}$ These schemes were incorporated, generally as companies limited by guarantee. ${ }^{69}$ The constitutions and terms of reference of these industry-based EDR schemes set out who could be a member of the respective schemes, the jurisdiction of the schemes and the processes for dealing with complaints. The key features of these financial sector EDR schemes (and schemes established by other industries, such as telecommunications and utilities) ${ }^{70}$ were the following:

- the schemes were funded by industry members and were generally cost-free for the consumer - producing a financial incentive for members to resolve as many consumer disputes as possible before the matter came to the scheme; ${ }^{71}$

- the schemes were independent from industry due to their governance structures (with consumer as well as industry representatives on the Board of the scheme) ${ }^{72}$

65 Banking and Financial Services Ombudsman Limited, Review of the Banking and Financial Services Ombudsman Scheme: Background Paper (June 2004) 18.

66 Banking and Financial Services Ombudsman Limited, Review of the Banking and Financial Services Ombudsman Scheme: Background Paper (June 2004) 19.

67 Banking and Financial Services Ombudsman Limited, Review of the Banking and Financial Services Ombudsman Scheme: Background Paper (June 2004) 39; Productivity Commission, Australian Government, Review of Australia's Consumer Policy Framework: Productivity Commission Inquiry Report, Final Report (April 2008) vol 2, 208.

${ }^{68}$ See further, Denise McGill, 'Are the Financial Services External Complaints Resolution Schemes Subject to Judicial Review?’ (2008) C\&SLJ 438, 448-455.

${ }^{69}$ Gail Pearson, Financial Services Law and Compliance in Australia (Cambridge University Press, 2009) 532; Paul O'Shea and Charles Rickett, 'In Defence of Consumer Law: The Resolution of Consumer Disputes' (2006) 28 Sydney Law Review 139, 154, 156.

70 See eg Chris Field, 'The Role of the Western Australian Energy Ombudsman and its Relationship with Regulators, Industry and Consumers' (2013) 41 ABLR 43, 45-46.

${ }^{71}$ Financial System Inquiry, Final Report (March 1997) 286; Colin Neave and John Pinnock, 'Setting the Scene: Industry-based Customer Dispute Resolution Schemes' (Presented at National Alternative Dispute Resolution Advisory Council, 4-5 September 2003, Sydney) 9. Neave and Pinnock noted that the Banking and Financial Services Ombudsman ('BFSO') charged a fee to small business customers: at 19.

72 Colin Neave and John Pinnock, 'Setting the Scene: Industry-based Customer Dispute Resolution Schemes' (Presented at National Alternative Dispute Resolution Advisory Council, 4-5 September 2003, Sydney) 10-11. 
- participating in the schemes was voluntary for the consumer and they could withdraw from the process at any time; ${ }^{73}$

- the schemes would not progress a complaint until the member had been given an opportunity to address and resolve it; ${ }^{74}$

- decision-making processes were not legalistic, legal representation was not encouraged, and disputes were determined according to good industry practice and what would be fair in all the circumstances, as well as law; $;^{75}$ and

- if the EDR scheme made a determination and it was accepted by the consumer, it was binding on the scheme member - whereas the consumer was not bound by the decision and could take the matter to court. ${ }^{76}$

In 1997, ASIC announced that licences issued to investment advisers under s 784 of the Corporations Law would be made subject to certain conditions including that the licensee have an internal complaints handling procedure and also be a member of an EDR scheme that had been approved by ASIC. ${ }^{77}$ This was given statutory force in 1998 under Corporations Regulations 1990 (Cth), which provided that if a licensee 'gives investment advice to a retail investor', the licensee 'must be a member of an external complaints resolution scheme approved by the Commission' and have internal complaints-handling procedures in place. ${ }^{78}$ (However, it was not until 2002 that similar requirements were articulated under the Corporations Act 2001 (Cth), as amended by the Financial Services Reform Act 2001 (Cth), which were applicable to the broader financial services industry.)

The external complaints resolution schemes were to be approved by ASIC in accordance with guidelines set out in the Australian Securities and Investments Commission Act 1989 (Cth) ('ASIC Act') s 12FA, which came into effect in July $1998 .^{79}$ This section provided that ASIC could not approve an industry code unless ASIC was satisfied with the procedures in relation to the resolution of disputes between the providers of financial services and consumers. The section set out certain guidelines for EDR procedures, including the following:

- the EDR scheme rules do not permit a complaint or dispute to be considered unless it has first been lodged with the relevant corporation and: (i) has been resolved by the

73 Banking and Financial Services Ombudsman Limited, Review of the Banking and Financial Services Ombudsman Scheme: Background Paper (June 2004) 13-14.

${ }^{74}$ Colin Neave and John Pinnock, 'Setting the Scene: Industry-based Customer Dispute Resolution Schemes' (Presented at National Alternative Dispute Resolution Advisory Council, 4-5 September 2003, Sydney) 19.

75 Colin Neave and John Pinnock, 'Setting the Scene: Industry-based Customer Dispute Resolution Schemes' (Presented at National Alternative Dispute Resolution Advisory Council, 4-5 September 2003, Sydney) 20.

${ }^{76}$ Colin Neave and John Pinnock, 'Setting the Scene: Industry-based Customer Dispute Resolution Schemes' (Presented at National Alternative Dispute Resolution Advisory Council, 4-5 September 2003, Sydney) 20; Paul O'Shea, 'Underneath the Radar: The Largely Unnoticed Phenomenon of Industry based Consumer Dispute Resolution Schemes in Australia' (2004) 15 ADRJ 156, 159.

77 ASIC Policy Statement 121, Investment advisory services: retail investor protection requirements (3 March 1997); see Financial Industry Complaints Service Ltd v Deakin Financial Services Pty Ltd (2006) 157 FCR 229, 231 [4] ('FICS v Deakin'). Section 786 of the Corporations Law provided that an investment adviser's licence was subject to such restrictions as were prescribed.

${ }^{78}$ Corporations Regulations 1990 (Cth) reg 7.3.02B(4) as amended by Corporations Regulations (Amendment) 1998 No 161 (Cth) reg 3.1.

${ }^{79}$ Australian Securities and Investments Commission Act 1989 (Cth) s 12FA, as inserted by Financial Sector Reform (Consequential Amendments) Act 1998 (Cth) sch 2 item 7. 
corporation, but not to the satisfaction of the complainant; or (ii) has not been resolved by the corporation and 90 days have elapsed since the complaint or dispute was lodged;

- the EDR scheme rules provide for any systemic, persistent or deliberate conduct to be reported to ASIC;

- the EDR scheme operates free of charge to the complainant;

- the EDR scheme covers a sufficiently broad range of complaints, with the terms of reference of the scheme to be determined after consultation with consumer organisations and ASIC;

- the EDR procedures accord with the principles of natural justice (including that information used by the decision-maker is provided to the complainant unless prohibited by law, and that reasons for decisions are given in writing);

- the EDR scheme rules provide for decisions to be made by reference to what is fair in all the circumstances, observing applicable law and relevant judicial authority and having regard to good practice in the relevant industry; and

- decisions made under the EDR scheme rules will be observed by the relevant corporations. ${ }^{80}$

In 1999, ASIC released Policy Statement 139, providing further information on the matters that it would take into account when deciding whether to approve an external complaints resolution scheme. ${ }^{81}$ This Policy Statement was based on the principles underlying the Benchmarks for Industry-based Customer Dispute Resolution Schemes, which were released by the Commonwealth Government in August 1997. ${ }^{82}$

In 2002, the Financial Services Reform Act 2001 (Cth) amended the Corporations Act to introduce a new regulatory framework for the financial services industry, including a single licensing regime for financial advice and dealings in relation to financial products. ${ }^{83}$ Any entity that operates a financial services business must now hold an Australian financial services licence or be authorised by a licensee. ${ }^{84}$ This new regulatory regime provides that all financial services licensees that provide financial services to persons as retail clients must have an appropriate dispute resolution system. ${ }^{85}$ These licensees need to have both an internal dispute resolution procedure and also membership of one or more EDR schemes approved by ASIC. ${ }^{86}$ The internal and external arrangements need to cover all complaints against the licensee that are made by retail clients in connection with the provision of financial services covered by the

\footnotetext{
${ }^{80}$ Australian Securities and Investments Commission Act 1989 (Cth) s 12FA(2)(a)-(d),(g),(h),(l), as inserted by Financial Sector Reform (Consequential Amendments) Act 1998 (Cth) sch 2 item 7. Section 12FA was initially retained under the Australian Securities and Investments Commission Act 2001 (Cth), but then repealed under the Financial Services Reform Act 2001 (Cth) sch 1 item 27.

81 Australian Securities and Investments Commission, Policy Statement 139: Approval of external complaints resolution schemes (8 July 1999).

${ }^{82}$ Banking and Financial Services Ombudsman Limited, Review of the Banking and Financial Services Ombudsman Scheme: Background Paper (June 2004) 14. The key principles were accessibility, independence, fairness, accountability, efficiency and effectiveness: at 15.

${ }^{83}$ Financial Services Reform Act 2001 (Cth) sch 1 item 1.

${ }^{84}$ Corporations Act 2001 (Cth) s 911A, as inserted by Financial Services Reform Act 2001 (Cth) sch 1 item 1.

${ }^{85}$ Corporations Act 2001 (Cth) s 912A(1)(g), as inserted by Financial Services Reform Act 2001 (Cth) sch 1 item 1.

${ }^{86}$ Corporations Act 2001 (Cth) s 912A(2), as inserted by Financial Services Reform Act 2001 (Cth) sch 1 item 1.
} 
licence. ${ }^{87}$ Equivalent obligations are also imposed on unlicensed product issuers and unlicensed secondary sellers. ${ }^{88}$ (All the legislative requirements concerning membership of ASICapproved EDR schemes have now been replaced by an obligation of AFCA membership. ${ }^{89}$ )

ASIC approved a total of eight EDR schemes in accordance with Policy Statement 139 between 1999 and 2008. ${ }^{90}$ Although s 12FA had been repealed by the Financial Services Reform Act 2001 (Cth), ${ }^{91}$ ASIC's policy regarding the approval of EDR schemes remained in force under Policy Statement 139 (with legislative authority for approval moving from the ASIC Act to the Corporations Regulations 2001 (Cth)). ${ }^{92}$ The first seven schemes to be approved by ASIC were the Financial Industry Complaints Service ('FICS'), Insurance Enquiries and Complaints, ABIO, Credit Union Dispute Resolution Centre, Insurance Brokers Dispute Facility, Financial Co-operative Dispute Resolution Scheme and Mortgage Industry Ombudsman Service:

- In October 1999, FICS was the first scheme to be approved by ASIC in accordance with Policy Statement $139 .^{93}$ FICS was formerly the Life Insurance Complaints Service, and derived from a scheme created in 1991 by the Life Insurance Federation

${ }^{87}$ Corporations Act 2001 (Cth) s 912A(2)(a)(ii),(b)(ii), as inserted by Financial Services Reform Act 2001 (Cth) sch 1 item 1. Note that if the Superannuation Complaints Tribunal could deal with all retail client complaints about the financial products and services provided, it was not necessary to join an ASIC-Approved EDR scheme: Corporations Act 2001 (Cth) s 912A(2)(b)(ii); ASIC, Regulatory Guide 165: Licensing: Internal and external dispute resolution (May 2018) 5.

${ }^{88}$ Corporations Act 2001 (Cth) s 1017G(2). Similarly, from April 2010 the National Consumer Credit Protection Act 2009 (Cth) s 47(1)(h),(i) required credit licensees to have an internal dispute resolution procedure that complied with ASIC standards as well as membership of an ASIC-approved EDR scheme. Credit representatives of licensees also were required to have separate membership of an ASIC-approved EDR scheme: National Consumer Credit Protection Act 2009 (Cth) ss 64(5)(c), 65(6)(c); ASIC, Regulatory Guide 165: Licensing: Internal and external dispute resolution (May 2018) 6.

${ }^{89}$ Corporations Act 2001 (Cth) s 912A(1)(g),(2), as amended by Treasury Laws Amendment (Putting Consumers First-Establishment of the Australian Financial Complaints Authority) Act 2018 (Cth) sch 1 item 32, sch 2 item 2; Corporations Act 2001 (Cth) s 1017G(1),(2)(b)(i), as amended by Treasury Laws Amendment (Putting Consumers First-Establishment of the Australian Financial Complaints Authority) Act 2018 (Cth) sch 1 item 33, sch 2 item 4; National Consumer Credit Protection Act 2009 (Cth) ss 47(1)(i), 64(5)(c), 65(6)(c) as amended by Treasury Laws Amendment (Putting Consumers First-Establishment of the Australian Financial Complaints Authority) Act 2018 (Cth) sch 1 item 35.

90 ASIC, 'ASIC-approved dispute resolution schemes' <https://asic.gov.au/regulatory-resources/financialservices/dispute-resolution/asic-approved-dispute-resolution-schemes/>; ASIC, Dispute resolution - Review of RG 139 and RG 165, Consultation Paper 102 (September 2008) 12; Review of the Financial System External Dispute Resolution and Complaints Framework: Final Report (April 2017) 35 [3.9]-[3.10].

${ }^{91}$ Financial Services Reform Act 2001 (Cth) sch 1 item 27.

92 ASIC, Licensing: External and internal dispute resolution procedures, Consultation Paper 23 (June 2001) 7 , 14. Policy Statement 139 was issued on 8 July 1999 and rebadged as a regulatory guide on 5 July 2007: ASIC, Approval and oversight of external dispute resolution schemes, Regulatory Guide 139 (June 2013) 2. ASIC had legislative power to approve EDR schemes under Australian Securities and Investments Commission Act 1989 (Cth) s 12FA from 1 July 1998 until 10 March 2002: Financial Sector Reform (Consequential Amendments) Act 1998 (Cth) sch 2 item 7; Financial Services Reform Act 2001 (Cth) sch 1 item 27. ASIC's approval power then shifted to the Corporations Regulations 2001 (Cth) regs 7.6.02(4), 7.9.77(4) from 11 March 2002: Corporations Amendment Regulations (No 4) 2001 (Cth) sch 1 item 15. ASIC was also given approval power under National Consumer Credit Protection Regulations 2010 (Cth) reg 10(4) from 1 July 2010. When deciding whether to approve an EDR scheme, the Regulations provided that ASIC must consider the accessibility, independence, fairness, accountability, efficiency and effectiveness of the scheme, and any other matter ASIC considered relevant: Corporations Regulations 2001 (Cth) regs 7.6.02(3), 7.9.77(3) as inserted by Corporations Amendment Regulations (No 4) 2001 (Cth) sch 1 item 15; National Consumer Credit Protection Regulations 2010 (Cth) reg 10(3).

${ }^{93}$ Financial Industry Complaints Service Limited, Annual Report 2000 (2001) 12. 
of Australia Incorporated. ${ }^{94}$ In 1999, when the Complaints Service changed its name to the FICS, it expanded its role from dealing only with complaints in the life insurance industry to dealing with those across the financial services industry. ${ }^{95}$ (In September 1998 ASIC had already approved the Life Insurance Complaints Service for the purposes of considering complaints about licensees who provided retail investment advice. $)^{96}$

- In August 2000, the Insurance Enquiries and Complaints scheme was the second scheme to be approved under Policy Statement 139. ${ }^{97}$ It was established in 1991 by the Insurance Council of Australia as the General Insurance Claims Review Panel, and later became the Insurance Ombudsman Service ('IOS') in 2004. ${ }^{98}$ It dealt with complaints against general insurance providers.

- In September 2001, the ABIO scheme became the third dispute resolution scheme to be approved by ASIC under Policy Statement 139. ${ }^{99}$ As noted above, it was later renamed the BFSO. ${ }^{100}$

- In August 2002, the Credit Union Dispute Resolution Centre scheme became the fourth scheme to be approved by ASIC under Policy Statement 139. ${ }^{101}$ It commenced as the Credit Union Dispute Reference Centre in 1996 to resolve disputes between credit unions and their customers. ${ }^{102}$

- In November 2002, the Insurance Brokers Dispute Facility, which was established in 1996 by the National Insurance Brokers Association of Australia, became the fifth scheme to be approved by ASIC. ${ }^{103}$ It incorporated in 2003 as the Insurance Brokers

\footnotetext{
${ }^{94}$ In 1991, the Life Insurance Federation of Australia Incorporated set up a Complaints Review Committee to resolve complaints by policy-holders: FICS v Deakin (2006) 157 FCR 229, 231 [2]. The Life Insurance Complaints Services Limited was incorporated in 1995, as a company limited by guarantee, to take over the activities of the Federation and to operate that EDR scheme: 231 [3].

${ }^{95}$ FICS v Deakin (2006) 157 FCR 229, 232 [6]; National Mutual Life Association of Australasia Ltd v Financial Industry Complaints Service Ltd [2006] VSC 121 (3 April 2006) [12].

${ }^{96}$ FICS v Deakin (2006) 157 FCR 229, 232 [5].

97 ASIC, ‘ASIC Approves General Insurance Code of Practice and Insurance Enquiries and Complaints Scheme' (Information Release, 00/026, 26 August 2000) <https://download.asic.gov.au/media/1339640/ir00-026.pdf>.

${ }^{98}$ Gail Pearson, 'The Place of Codes of conduct in Regulating Financial Services' (2006) 15 Griffith Law Review 333, 341; Community Solutions, La Trobe University and University of Western Sydney, Review of the Financial Industry Complaints Service 2002 - What are the Issues? (August 2002) 8; Colin Neave and John Pinnock, 'Setting the Scene: Industry-based Customer Dispute Resolution Schemes' (Presented at National Alternative Dispute Resolution Advisory Council, 4-5 September 2003, Sydney) 5.
}

99 ASIC, 'ASIC approves banking complaints scheme' (Media Release, 01/339, 21 September 2001) $<$ https://asic.gov.au/about-asic/news-centre/find-a-media-release/2001-releases/01339-asic-approves-bankingcomplaints-scheme/>; Banking and Financial Services Ombudsman Limited, Review of the Banking and Financial Services Ombudsman Scheme: Background Paper (June 2004) 5.

${ }^{100}$ See above $\mathrm{n} 66$ and the accompanying text.

${ }^{101}$ Credit Union Dispute Resolution Centre, Review of the Credit Union Dispute Resolution Centre: Background Paper (June 2005) 12.

${ }^{102}$ Credit Union Dispute Resolution Centre, Review of the Credit Union Dispute Resolution Centre: Background Paper (June 2005) 8; Gail Cork, 'ADR brings high interest returns in financial disputes - the Credit Union Dispute Reference Centre' (1998) 1(2) ADR Bulletin 34, 34.

${ }^{103}$ Insurance Brokers Disputes Limited, Annual Report: 1 January 2002-31 December 2002 (2003) 2; Insurance Brokers Disputes Limited, Insurance Brokers Disputes Ltd Annual Report: 1 January 2003-31 December 2003 (2004) 5. 
Disputes Limited. ${ }^{104}$ It handled complaints by retail clients against insurance brokers and other insurance intermediaries.

- In January 2003, the Financial Co-operative Dispute Resolution Scheme it became the sixth scheme approved by ASIC under Policy Statement 139. ${ }^{105}$ It replaced the Credit Union Ombudsman scheme. ${ }^{106}$ The scheme dealt with complaints from consumers about those Australian credit unions and building societies who were members of the scheme. ${ }^{107}$

- In December 2003, the Mortgage Industry Ombudsman Service became the seventh scheme to be approved by ASIC under Policy Statement $139 .{ }^{108}$ It originally covered complaints against members who had dealt with consumers in respect of real estate mortgage secured lending, but expanded its jurisdiction to cover a broader range of financial products, as well as directly incidental products and services, when it adopted the name Credit Ombudsman Service Limited ('COSL') in 2004. ${ }^{109}$ It became the Credit and Investments Ombudsman ('CIO') in 2014. ${ }^{110}$

FOS was created in March 2008 by the merger of three pre-existing ASIC-approved EDR schemes (the BFSO, FICS and the IOS). ${ }^{111}$ FOS received ASIC approval as an EDR scheme in May 2008, and two other ASIC-approved EDR schemes (the Credit Union Dispute Resolution Centre and the Insurance Brokers Disputes) also joined FOS in January 2009. ${ }^{112}$ The Financial Co-operative Dispute Resolution Scheme ceased operations in 2009. ${ }^{113}$ Accordingly, by 2009 , only two industry-established EDR schemes remained: FOS and COSL which, as noted above, became the CIO in 2014.

In 2016, the Australian Government commissioned a review into the financial system external dispute resolution framework ('EDR Review'). The review panel provided a final report in

${ }^{104}$ Insurance Brokers Disputes Limited, Insurance Brokers Disputes Ltd Annual Report: 1 January 2003-31 December 2003 (2004) 5.

105 ASIC, 'New complaints scheme approved by ASIC', (Media Release, 03-030, 30 January 2003) $<$ https://asic.gov.au/about-asic/news-centre/find-a-media-release/2003-releases/03-030-new-complaintsscheme-approved-by-asic/>.

${ }^{106}$ Credit Union Dispute Resolution Centre, Review of the Credit Union Dispute Resolution Centre: Background Paper (June 2005) 11.

107 ASIC, 'New complaints scheme approved by ASIC', (Media Release, 03-030, 30 January 2003) $<$ https://asic.gov.au/about-asic/news-centre/find-a-media-release/2003-releases/03-030-new-complaintsscheme-approved-by-asic/>.

108 'Consumer complaints scheme approved', Sydney Morning Herald (23 December 2003) $<$ https:/www.smh.com.au/national/consumer-complaints-scheme-approved-20031223-gdi174.html>.

${ }^{109}$ Credit Ombudsman Service Limited, Annual Report 2005 (2005) 5.

${ }^{110}$ Review of the Financial System External Dispute Resolution and Complaints Framework: Final Report (April 2017) 35 [3.11].

${ }^{111}$ ASIC, Feedback from submissions to the Financial Ombudsman Service Limited's new Terms of Reference, Report 182 (December 2009) 5.

${ }^{112}$ Review of the Financial System External Dispute Resolution and Complaints Framework: Final Report (April 2017) 35 [3.10]; ASIC, Feedback from submissions to the Financial Ombudsman Service Limited's new Terms of Reference, Report 182 (December 2009) 5.

113 See Australian Securities and Investments Commission ('ASIC'), 'ASIC-approved Dispute Resolution Schemes’ <https://asic.gov.au/regulatory-resources/financial-services/dispute-resolution/asic-approved-disputeresolution-schemes/>. 
April 2017, recommending the establishment of a single EDR body. ${ }^{114}$ The benefits of having a single EDR body for all financial disputes are outlined below. The Government accepted the recommendation and announced that a new EDR body, AFCA, would be created. ${ }^{115}$ AFCA commenced operations in November 2018 and replaced not only the ASIC-approved FOS and CIO, but also the Superannuation Complaints Tribunal ('SCT'). ${ }^{116}$ In contrast to the industryestablished EDR schemes, the SCT was created in 1993 as a statutory tribunal and it operates within its own legislative framework. ${ }^{117}$ To replace the SCT and the Superannuation (Resolution of Complaints) Act 1993 (Cth), special provisions have been inserted into the Corporations Act outlining when complaints relating to superannuation can be made under the AFCA scheme, the special powers that AFCA has in dealing with superannuation complaints (such as the power to join parties, and the power to obtain information and documents), as well as setting out AFCA's powers in making determinations of superannuation complaints. ${ }^{118}$

\section{Consolidation of the financial services EDR schemes}

The existence of multiple EDR schemes with overlapping jurisdictions raises various issues: there is an increased risk of consumer confusion, consumers with similar complaints can receive inconsistent outcomes, it can be difficult for consumers to progress disputes involving firms that are members of different schemes, and there is a duplication in costs for industry and the regulator. ${ }^{119}$

As early as 1997, the Wallis Report had highlighted the problems associated with the proliferation of EDR schemes. The Report noted that consumers could feel 'bewildered in the face of the diversity of schemes. ${ }^{120}$ While the Report did not advocate for the amalgamation of the schemes, it supported the adoption of a central referral service, funded by retail financial service providers, for all consumers of retail financial products and services. ${ }^{121}$

\footnotetext{
${ }^{114}$ Review of the Financial System External Dispute Resolution and Complaints Framework: Final Report (April 2017).

115 Commonwealth, Parliamentary Debates, House of Representatives, 9 May 2017, 4064 (Scott Morrison, Treasurer).

${ }^{116}$ Australian Financial Complaints Authority, 'About AFCA'<https://www.afca.org.au/about-afca/>; Financial Ombudsman Service, 'AFCA information for members' <https://www.fos.org.au/members/afca-information-formembers $/>$.

${ }^{117}$ Financial System Inquiry, Final Report (March 1997) 286; Superannuation (Resolution of Complaints) Act 1993 (Cth) s 6.

${ }^{118}$ See Corporations Act 2001 (Cth) pt 7.10A (External dispute resolution) div 3 (Additional provisions relating to superannuation complaints).

${ }^{119}$ Review of the Financial System External Dispute Resolution and Complaints Framework: Final Report (April 2017) 8; Ian Ramsay, 'Improving Dispute Resolution in the Financial System' (2017) 28 ADRJ 191, 192. ASIC made similar points in 2000, highlighting that a proliferation of EDR schemes could result in greater costs for industry due to diseconomies of scale, greater costs for industry due to gaps and overlaps in complaint scheme coverage, inconsistent treatment of disputes by the various external schemes, consumer and industry confusion, regulatory uncertainty and increased costs for regulatory agencies: ASIC, 'Submission to the Inquiry on Industry Self-regulation' (January 2000) <http://archive.treasury.gov.au/documents/1132/PDF/037.pdf> 24.

${ }^{120}$ Financial System Inquiry, Final Report (March 1997) 287.

${ }^{121}$ Financial System Inquiry, Final Report (March 1997) 288. ASIC developed a complaints referral service on a trial basis in 1998: ASIC, 'Submission to the Inquiry on Industry Self-regulation' (January 2000) $<$ http://archive.treasury.gov.au/documents/1132/PDF/037.pdf $>29$. FICS, BFSO and the Insurance Enquiries and Complaints scheme also established a joint call centre in 2002, which was utilised by FICS, BFSO, IOS, Credit Union Dispute Reference Centre, Insurance Brokers Disputes, COSL and also the SCT, to refer consumer enquiries and reduce operating costs for participating schemes: Colin Neave and John Pinnock, 'Setting the Scene:
} 
In 2000, ASIC acknowledged 'the major contribution that the growth of effective selfregulatory mechanisms have made to consumer protection in the finance sector', but expressed doubt that the increasing number of EDR schemes would lead to more cost-effective consumer protection and market improvement. ${ }^{122}$ ASIC highlighted that there were several EDR schemes that had overlapping jurisdictions, such as schemes considering complaints about credit providers and related entities (the ABIO and the Credit Union Dispute Reference Centre), and in the insurance area (the Insurance Brokers Dispute Facility and both FICS and the Insurance Enquiries and Complaints scheme). ${ }^{123}$ The Financial Service Complaints Resolution Scheme had recently merged with FICS, ${ }^{124}$ and ASIC welcomed this merger as it would 'deliver cost savings to industry and more consistent complaints handling for consumers' - the two schemes had a very substantial degree of overlap in relation to complaints about licensees who provided investment advice to retail investors and complaints about responsible entities of managed investment schemes. ${ }^{125}$

ASIC also noted that financial institutions were often members of more than one EDR scheme: for example, larger banks could belong to the ABIO, the Insurance Enquiries and Complaints scheme and FICS (and previously the Financial Service Complaints Resolution Scheme). ${ }^{126}$ This was a key driver for the establishment of FICS in 1999 and also why several larger institutions argued for a single EDR scheme for the financial sector in their submissions to the 1997 Finance System Inquiry. ${ }^{127}$ However, like the Wallis Report, ASIC did not at this time support the establishment of a single Ombudsman scheme for the financial sector, but believed there was a need for further research on the rationalisation of EDR schemes. ASIC suggested that one possibility would be to move to three broad-based schemes (banking and credit; life insurance, investments and financial advice; and general insurance). ${ }^{128}$

In 2007, the BFSO, FICS and IOS made a joint submission in response to the Productivity Commission's Issues Paper Review of Australia's Consumer Policy Framework. The submission argued that 'streamlining the services of the ASIC approved EDR schemes as much as possible [would] only provide benefits to consumers'. ${ }^{129}$ The submission highlighted the

Industry-based Customer Dispute Resolution Schemes' (Presented at National Alternative Dispute Resolution Advisory Council, 4-5 September 2003, Sydney) 26; Banking and Financial Services Ombudsman Limited, Review of the Banking and Financial Services Ombudsman Scheme: Background Paper (June 2004) 43; Gail Pearson, Financial Services Law and Compliance in Australia (Cambridge University Press, 2009) 539.

122 ASIC, 'Submission to the Inquiry on Industry Self-regulation'

$<$ http://archive.treasury.gov.au/documents/1132/PDF/037.pdf $>24$.

123 ASIC, 'Submission to the Inquiry on Industry Self-regulation' (January 2000) $<$ http://archive.treasury.gov.au/documents/1132/PDF/037.pdf $>21$.

124 ASIC, 'Submission to the Inquiry on Industry Self-regulation' (January 2000) $<$ http://archive.treasury.gov.au/documents/1132/PDF/037.pdf $>20$.

125 ASIC, 'Submission to the Inquiry on Industry Self-regulation' (January 2000) $<$ http://archive.treasury.gov.au/documents/1132/PDF/037.pdf $>21$.

126 ASIC, 'Submission to the Inquiry on Industry Self-regulation' (January 2000) $<$ http://archive.treasury.gov.au/documents/1132/PDF/037.pdf $>22$.

127 ASIC, 'Submission to the Inquiry on Industry Self-regulation' (January 2000) $<$ http://archive.treasury.gov.au/documents/1132/PDF/037.pdf $>22$.

128 ASIC, 'Submission to the Inquiry on Industry Self-regulation' (January 2000) $<$ http://archive.treasury.gov.au/documents/1132/PDF/037.pdf $>25$.

129 Banking and Financial Services Ombudsman Ltd, Financial Industry Complaints Service and Insurance Ombudsman Service, Submission in response to the Consumer Policy Framework Productivity Commission Issues Paper (June 2007) 17. 
success of a joint telephone referral centre (which by 2007 involved all of the ASIC-approved EDR schemes as well as the SCT), and noted that - given the success of that initiative - the $\mathrm{BFSO}, \mathrm{FICS}$ and IOS envisaged further cooperation in the provision of EDR services in the future. ${ }^{130}$ The BFSO, FICS and IOS suggested that future convergence of the operations of ASIC-approved EDR schemes could involve 'having a single name and point of entry for consumers but at the same time retaining expertise in the various and distinct areas within the wider financial services industry. ${ }^{131}$ The Productivity Commission adopted this suggestion, recommending that financial EDR services be further enhanced 'through integration of the existing bodies into a single umbrella scheme to provide one referral and complaint pathway, while allowing independent governance of its subsidiary schemes'. ${ }^{132}$ The Productivity Commission in its 2008 report concluded that, on balance, 'the mandated introduction of a single scheme, like the UK Financial Services Ombudsman, [was] not warranted at this stage.' 133

However, by 2016 sentiment had begun to change regarding the consolidation of the ASICapproved EDR schemes into one scheme. Only two industry-based schemes remained: FOS and CIO. In November 2016, as part of its Review of the Four Major Banks: First Report, the House of Representatives Standing Committee on Economics recommended that a Banking and Financial Sector Tribunal be established by 1 July 2017 to handle complaints from consumers and small businesses, replacing FOS, CIO and the SCT. ${ }^{134}$ The Committee took into account submissions made in response to the EDR Review's Issues Paper, which was released in September 2016. ${ }^{135}$ The Committee therefore drew similar conclusions to those later drawn by the EDR Review Panel (discussed below), despite ultimately recommending a statutory tribunal rather than an industry-established EDR scheme. ${ }^{136}$

The Standing Committee believed that the system of multiple EDR schemes was 'overly complex and overly legalistic'. ${ }^{137}$ The Committee noted that the multi-scheme framework was very duplicative and the overlap in the different jurisdictions of the schemes risked creating confusion for consumers. ${ }^{138}$ In regards to duplication, ASIC highlighted in its EDR Review submission that the EDR schemes each had their own governance arrangements with separate

${ }^{130}$ Banking and Financial Services Ombudsman Ltd, Financial Industry Complaints Service and Insurance Ombudsman Service, Submission in response to the Consumer Policy Framework Productivity Commission Issues Paper (June 2007) 17.

131 Banking and Financial Services Ombudsman Ltd, Financial Industry Complaints Service and Insurance Ombudsman Service, Submission in response to the Consumer Policy Framework Productivity Commission Issues Paper (June 2007) 17.

132 Productivity Commission, Australian Government, Review of Australia's Consumer Policy Framework: Productivity Commission Inquiry Report, Final Report (April 2008) vol 2, 209.

133 Productivity Commission, Australian Government, Review of Australia's Consumer Policy Framework: Productivity Commission Inquiry Report, Final Report (April 2008) vol 2, 207.

${ }^{134}$ House of Representatives Standing Committee on Economics, Parliament of Australia, Review of the Four Major Banks: First Report (2016) 5.

135 Review of the Financial System External Dispute Resolution and Complaints Framework: Issues Paper (September 2016).

136 House of Representatives Standing Committee on Economics, Parliament of Australia, Review of the Four Major Banks: First Report (2016) 5.

${ }^{137}$ House of Representatives Standing Committee on Economics, Parliament of Australia, Review of the Four Major Banks: First Report (2016) 5.

${ }^{138}$ House of Representatives Standing Committee on Economics, Parliament of Australia, Review of the Four Major Banks: First Report (2016) 6. 
boards, case management systems and support infrastructure, administration and regulatory reporting arrangements for licensees and representatives, and statistical, systemic issues and serious misconduct processes and reporting requirements. ${ }^{139}$ By contrast, CIO had made a submission to the EDR Review arguing that the existence of two ASIC-approved EDR schemes produced better outcomes for financial services providers, consumers and regulators as it meant that the schemes could benchmark their performance against each other. ${ }^{140}$ The Standing Committee rejected this argument, noting that it was 'hard to imagine how the benchmarking referred to by the CIO could meaningfully occur' given the difficulties in comparing and ensuring consistent outcomes for FOS and CIO complainants due to the use of conciliation and different reporting standards. ${ }^{141}$ Moreover, the Committee observed that tribunals operating in other sectors achieved good outcomes for consumers without competition between 'duplicative schemes'. ${ }^{142}$

In December 2016, the Interim Report of the EDR Review was released. It found that the presence of two ASIC-approved EDR schemes with overlapping jurisdictions gave rise to various problems, particularly: 'consumer confusion and difficulties in achieving comparable outcomes for consumers who have similar complaints; and unnecessary duplicative costs and an inefficient allocation of resources for the industry (based on the need to establish and run two schemes) and for the regulator (based on the need to approve and oversee multiple schemes)'. ${ }^{143}$ The Panel also noted that 'where it is the financial firms (but not consumers) who have a choice of scheme for dispute resolution, it is not clear that competitive tension drives innovation and better outcomes for consumers. ${ }^{144}$ The Interim Report recommended that there be a single industry ombudsman scheme for all financial, credit and investment disputes (other than superannuation disputes) to replace FOS and CIO, and that the SCT should transition into an industry ombudsman scheme for superannuation disputes. ${ }^{145}$ However, in its Final Report, the Panel concluded that replacing FOS, CIO and SCT with a single, industry-based EDR body would be more efficient.

In the Final Report, the EDR Review Panel noted that the process of the consolidation of industry-based EDR schemes (for example, the merger of BFSO, FICS and IOS to create FOS) had 'improved scheme efficiencies, removed uncertainty for consumers and reduced the overlaps between the schemes.' ${ }^{146}$ The Panel outlined the problems of the existing multi-

${ }^{139}$ House of Representatives Standing Committee on Economics, Parliament of Australia, Review of the Four Major Banks: First Report (2016) 6-7; ASIC, Review of the financial system external dispute resolution framework: Submission by the Australian Securities and Investments Commission (October 2016) $<$ https://static.treasury.gov.au/uploads/sites/1/2017/06/R2016-

002_Australian_Securities_and_Investments_Commission.pdf $>30-31$.

${ }^{140}$ House of Representatives Standing Committee on Economics, Parliament of Australia, Review of the Four Major Banks: First Report (2016) 7.

${ }^{141}$ House of Representatives Standing Committee on Economics, Parliament of Australia, Review of the Four Major Banks: First Report (2016) 7.

${ }^{142}$ House of Representatives Standing Committee on Economics, Parliament of Australia, Review of the Four Major Banks: First Report (2016) 7.

${ }^{143}$ Review of the Financial System External Dispute Resolution and Complaints Framework: Interim Report (December 2016) 144 [6.6].

${ }^{144}$ Review of the Financial System External Dispute Resolution and Complaints Framework: Interim Report (December 2016) 144 [6.7].

145 Review of the Financial System External Dispute Resolution and Complaints Framework: Interim Report (December 2016) 144, 149.

${ }^{146}$ Review of the Financial System External Dispute Resolution and Complaints Framework: Final Report (April 2017) 103. See also ASIC, Review of the financial system external dispute resolution framework: Submission by 
scheme framework: the overlap between the EDR schemes and the risk of inconsistent outcomes across EDR schemes; the difficulties in pursuing disputes that involve multiple financial firms; consumer confusion; and the imposition of unnecessary costs for financial firms, ASIC and stakeholders.

First, a consumer could have a very different dispute resolution experience and outcome depending on which ASIC-approved EDR scheme the relevant financial firm was a member of, or how the consumer had obtained the product - for example, whether life insurance was obtained within or outside superannuation determined if FOS or SCT dealt with the dispute. ${ }^{147}$ Despite having jurisdictional overlap, FOS, CIO and SCT had different processes for dealing with disputes, such as fast-track processes for certain disputes, different decision-making models (e.g. the use of panels or a single ombudsman), and different decision-making criteria. ${ }^{148}$ These factors all had the potential to affect the consumer's EDR experience and the outcome of the dispute.

In particular, there was a high level of overlap in the jurisdictions of FOS and CIO: less than one percent of the disputes in 2015-2016 concerned matters of exclusive jurisdiction to CIO and 29 percent concerned matters of exclusive jurisdiction to FOS - 70 percent of the total disputes related to matters in which FOS and CIO had overlapping jurisdiction. ${ }^{149}$ FOS and CIO had overlapping jurisdiction in relation to credit, deposit taking, payment systems and investments disputes. ${ }^{150}$ There were also overlaps in jurisdiction between FOS and SCT (life insurance disputes) and FOS, CIO and SCT (financial advice disputes). ${ }^{151}$ However, FOS and CIO had different definitions of 'financial services', so a particular type of claim could be precluded from one scheme where it may have been within the jurisdiction of the other. ${ }^{152}$ Also, both FOS and CIO had a monetary limit for claims - whereas the SCT had no monetary limit on its jurisdiction. ${ }^{153}$

The Panel emphasised that 'consumers do not have the choice of which EDR body resolves their disputes' and that consumers were unlikely to decide which financial product or service to buy on the basis of the EDR scheme to which the firm belonged. ${ }^{154} \mathrm{CIO}$ suggested that EDR schemes could not 'evolve, innovate and go beyond their minimum jurisdiction' if they needed

the Australian Securities and Investments Commission (October 2016) $<$ https://static.treasury.gov.au/uploads/sites/1/2017/06/R2016-

002_Australian_Securities_and_Investments_Commission.pdf $>39$.

${ }^{147}$ Review of the Financial System External Dispute Resolution and Complaints Framework: Final Report (April 2017) 104.

${ }^{148}$ Review of the Financial System External Dispute Resolution and Complaints Framework: Final Report (April 2017) 104.

${ }^{149}$ Review of the Financial System External Dispute Resolution and Complaints Framework: Final Report (April 2017) 103.

${ }^{150}$ Review of the Financial System External Dispute Resolution and Complaints Framework: Final Report (April 2017) 103.

${ }^{151}$ Review of the Financial System External Dispute Resolution and Complaints Framework: Final Report (April 2017) 103.

${ }^{152}$ Review of the Financial System External Dispute Resolution and Complaints Framework: Final Report (April 2017) 104.

${ }^{153}$ Review of the Financial System External Dispute Resolution and Complaints Framework: Final Report (April 2017) $57,71,83,104$. The maximum value per claim that could be considered by FOS or CIO was $\$ 500,000$, but each accepted that a single dispute could involve more than one claim.

${ }^{154}$ Review of the Financial System External Dispute Resolution and Complaints Framework: Final Report (April 2017) 105. 
to produce comparable outcomes either within their scheme or between the two ASICapproved schemes. ${ }^{155}$ However, the Panel determined that there was little evidence that schemes innovated by learning from the processes of other schemes. ${ }^{156}$ Accordingly, the Panel concluded that giving a single EDR body responsibility for dealing with all financial disputes would improve consistency in decision making and processes. ${ }^{157}$

Second, the existence of multiple EDR schemes could result in situations in which a dispute involved members of different schemes. The Panel highlighted that, in these circumstances, a consumer may be required to pursue the dispute through two schemes, which would require navigating two different sets of procedures and dealing with different case managers. ${ }^{158}$ As the powers of an ASIC-approved EDR scheme derived from the contract between the financial firm and the scheme, rather than deriving power from statute (like the SCT), these schemes could not join a third party to the dispute if the third party was a member of the other scheme. ${ }^{159}$ The Panel observed that the number of disputes involving members of different schemes was likely to continue to increase because more financial products are being sold as a bundle with multiple parties involved. ${ }^{160}$ It concluded that where a consumer must pursue a dispute through multiple schemes, there are various inefficiencies for the consumer and the financial firms that are parties to the dispute. ${ }^{161}$

Third, the Panel accepted that the multi-scheme EDR framework caused consumer confusion. This led to costs to the consumer, such as the increased risk of consumer fatigue and delay in the dispute's resolution, and costs to the EDR schemes due to resource expenditure in crossreferring disputes between each other. ${ }^{162}$ In 2015-2016, FOS referred close to 1,000 disputes to CIO and SCT, and CIO transferred four percent of its complaints and 16 percent of its enquiries to FOS. ${ }^{163}$

Fourth, the Panel found that the 'inherent duplication resulting from multiple bodies performing essentially the same function ${ }^{\prime 64}$ resulted in an inefficient allocation of resources by imposing unnecessary costs on financial firms and potentially consumers, as well as on

${ }^{155}$ Credit and Investments Ombudsman, 'Response by the Credit and Investments Ombudsman to the Interim Report by the EDR Review Panel' (January 2017) $12<\mathrm{https}$ //treasury.gov.au/consultation/dispute-resolutioncomplaints-framework-interim-report/>. See also Review of the Financial System External Dispute Resolution and Complaints Framework: Final Report (April 2017) 111-112.

${ }^{156}$ Review of the Financial System External Dispute Resolution and Complaints Framework: Final Report (April 2017) 106.

${ }^{157}$ Review of the Financial System External Dispute Resolution and Complaints Framework: Final Report (April 2017) 106.

${ }^{158}$ Review of the Financial System External Dispute Resolution and Complaints Framework: Final Report (April 2017) 106.

${ }^{159}$ Review of the Financial System External Dispute Resolution and Complaints Framework: Final Report (April 2017) 106.

${ }^{160}$ Review of the Financial System External Dispute Resolution and Complaints Framework: Final Report (April 2017) 107.

${ }^{161}$ Review of the Financial System External Dispute Resolution and Complaints Framework: Final Report (April 2017) 107.

162 Review of the Financial System External Dispute Resolution and Complaints Framework: Final Report (April 2017) 109.

${ }^{163}$ Review of the Financial System External Dispute Resolution and Complaints Framework: Final Report (April 2017) 108.

${ }^{164}$ Review of the Financial System External Dispute Resolution and Complaints Framework: Final Report (April 2017) 111. 
ASIC and stakeholders (such as industry and consumer groups that provide assistance to consumers with their disputes, engage in advocacy and participate in reviews of the schemes). ${ }^{165}$ ASIC had highlighted, in its submission in response to the EDR Review Panel's Issues Paper, that there were various areas of duplication in the EDR schemes. ${ }^{166}$ The Panel emphasised that these duplications imposed increased costs on the financial system as a whole', which would be avoided by a single-scheme model. ${ }^{167}$ ASIC had also noted the duplicative costs that it experienced as the regulator in overseeing two EDR schemes, including the ongoing monitoring of the schemes' statistical and systemic issues reporting and associated processes, oversight of independent reviews for each scheme, and overseeing the movement of members between schemes. ${ }^{168}$ The Panel concluded that the need to 'establish and run and ... approve and oversee multiple schemes, results in unnecessary duplicative costs and an inefficient allocation of resources.' 169

As well as considering the flaws of the multi-scheme framework, the Panel also gave further consideration to the issue of whether having two ASIC-approved schemes produced competition between the schemes, creating an incentive to innovate. CIO had argued that having multiple EDR schemes provides competition between schemes and leads to innovation. ${ }^{170}$ However, FOS rejected the notion that competition with CIO had been a driver for changes within FOS, ${ }^{171}$ and ASIC had stated that it did not believe that 'competition between EDR schemes enhances consumer outcomes': ${ }^{172}$

Dispute resolution is not a competitive market, and access to EDR does not drive consumer choice of financial product or service. The potential for firms to seek to switch to a lower cost scheme, on the basis that fees and costs are likely to be one of the most salient features of dispute resolution, is undesirable from a policy perspective and can inhibit innovation or efforts of schemes to extend beyond the minimum jurisdiction. ${ }^{173}$

The Panel re-iterated that as the financial firms, and not consumers, have the choice of which ASIC-approved EDR scheme to join, there was a risk that the schemes would compete on

\footnotetext{
${ }^{165}$ Review of the Financial System External Dispute Resolution and Complaints Framework: Final Report (April 2017) 110 - 111.

${ }^{166}$ See footnote 139 and the accompanying text.

${ }^{167}$ Review of the Financial System External Dispute Resolution and Complaints Framework: Final Report (April 2017) 110.

${ }^{168}$ Review of the Financial System External Dispute Resolution and Complaints Framework: Final Report (April 2017) 110.

${ }^{169}$ Review of the Financial System External Dispute Resolution and Complaints Framework: Final Report (April 2017) 111.

${ }^{170}$ Review of the Financial System External Dispute Resolution and Complaints Framework: Final Report (April 2017) 111.

${ }^{171}$ Review of the Financial System External Dispute Resolution and Complaints Framework: Final Report (April 2017) 112-113.

172 ASIC, Review of the financial system external dispute resolution framework: Submission by the Australian $\begin{array}{lllll}\text { Securities and } & \text { Commission } & \text { (October }\end{array}$ $<$ https://static.treasury.gov.au/uploads/sites/1/2017/06/R2016002_Australian_Securities_and_Investments_Commission.pdf $>39$.

${ }^{173}$ ASIC, Review of the financial system external dispute resolution framework: Submission by the Australian Securities and Investments Commission $\quad$ (October $<$ https://static.treasury.gov.au/uploads/sites/1/2017/06/R2016002_Australian_Securities_and_Investments_Commission.pdf $>39$.
} 
matters that were of interest to the firms, such as more restrictive terms of reference or lower membership fees. ${ }^{174}$ Also, there was little evidence that improvements to the schemes had been driven by competition; the evidence that innovations were more likely to be the result of independent reviews was found to be compelling. ${ }^{175}$ Accordingly, the Panel concluded that competition between the industry-based EDR schemes could not be expected to 'make the market for EDR services work in the long-term interests of consumers', competition was not the primary driver of innovation and did not provide the most effective outcomes for users. ${ }^{176}$ Additionally, the Panel noted that the proposed single EDR body would be subject to enhanced accountability mechanisms. ${ }^{177}$ These measures would include enhanced financial transparency, more frequent independent reviews and an independent assessor to review the handling of disputes. ${ }^{178}$ The Panel concluded that moving to a single EDR body that is subject to stronger oversight should create 'greater economies of scale, with pressure for the body to improve its effectiveness over time. ${ }^{\text {' }}$ '

The recommended body, AFCA, commenced operation in November $2018 .{ }^{180}$ Although it has only been in existence for a limited time, the Senate Legal and Constitutional Affairs References Committee, in a recent report examining the resolution of disputes in the financial system, stated that it supported the creation of AFCA - it also noted that those who made submissions to the Committee or who appeared as witnesses before the Committee as part of its inquiry generally welcomed the establishment of AFCA. ${ }^{181}$

\section{Conclusion}

In this article we have outlined the establishment and expansion, and then the consolidation, of the industry-established EDR schemes in the financial sector. EDR schemes provide a forum for consumers to resolve complaints or disputes in a manner that is faster and cheaper than the formal court system; they also provide an opportunity to improve industry standards of conduct and to improve relations between industry participants and consumers. ${ }^{182}$

However, the existence of multiple schemes for the resolution of disputes between financial service providers and consumers has been problematic in Australia. We have set out the problems that were caused by the multi-body EDR framework and have outlined why a single EDR body that can resolve all financial disputes should be more efficient and beneficial for

\footnotetext{
${ }^{174}$ Review of the Financial System External Dispute Resolution and Complaints Framework: Final Report (April 2017) 114-115.

${ }^{175}$ Review of the Financial System External Dispute Resolution and Complaints Framework: Final Report (April 2017) 115.

${ }^{176}$ Review of the Financial System External Dispute Resolution and Complaints Framework: Final Report (April 2017) 115.

${ }^{177}$ Review of the Financial System External Dispute Resolution and Complaints Framework: Final Report (April 2017) 116.

${ }^{178}$ Review of the Financial System External Dispute Resolution and Complaints Framework: Final Report (April 2017) 116.

${ }^{179}$ Review of the Financial System External Dispute Resolution and Complaints Framework: Final Report (April 2017) 119.

${ }^{180}$ See notes 114 to 118 above and accompanying text.

${ }^{181}$ Senate Legal and Constitutional Affairs References Committee, Parliament of Australia, Resolution of Disputes with Financial Service Providers within the Justice System (April 2019) [2.58], [3.27].

${ }^{182}$ ASIC, Approval and oversight of external dispute resolution schemes, Regulatory Guide 139 (June 2013 ) 12.
} 
consumers, financial firms and the regulator, ASIC. The merger of several EDR schemes in 2008 to create FOS reduced overlaps between the schemes and was said to have improved efficiencies and reduced uncertainty for consumers. ${ }^{183}$ The establishment of AFCA can therefore be seen as the final step in a history that initially saw an increase in the number of EDR schemes in the financial sector but more recently has seen consolidation of these schemes.

183 See above n 146. 